Boletín de la Sociedad Geológica Mexicana

VOLUMEN 65, NÚM. 2, 2013, P. 329-334

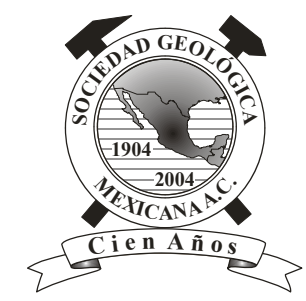

\title{
Calappa granulata (Linnaeus, 1758) (Crustacea, Decapoda, Brachyura, Calappidae) and Astiplax aspera n. gen., n. sp. (Crustacea, Decapoda, Brachyura, Goneplacidae) from the Asti sands Fm. (Late Pliocene) of S. Pietro (Asti, Piedmont, NW Italy)
}

\author{
Alessandro Garassino ${ }^{1, *}$, Giovanni Pasini ${ }^{2}$ \\ ${ }^{1}$ Museo di Storia Naturale, Sezione di Paleontologia, Corso Venezia 55, 20121 Milano, Italia. \\ ${ }^{2}$ Via Alessandro Volta 16, I-22070 Appiano Gentile (Como), Italia. \\ *alegarassino@gmail.com
}

\begin{abstract}
Two crabs from the Pliocene sands of S. Pietro (Asti, Piedmont, NW Italy) have been assigned to Calappa granulata (Linnaeus, 1758) (Calappidae De Haan, 1833) and to Astiplax aspera n. gen., n. sp. (Goneplacidae MacLeay, 1838). Although C. granulata has already been reported from the Pliocene of other Italian regions, the Piedmont specimen represents one of the most complete carapaces known to date in the fossil record of this extant species. The discovery of Astiplax n. gen., with A. aspera n. sp. increases the number of species of Goneplacidae from the Pliocene of Italy, limited to Goneplax rhomboides (Linnaeus, 1758) and G. sacci Crema, 1895.
\end{abstract}

Keywords: Crustacea, Decapoda, Brachyura, Late Pliocene, Italy.

\section{Resumen}

Dos cangrejos de las areniscas del Plioceno de S. Pietro (Asti, Piemonte, NO Italia) han sido asignados a Calappa granulata (Linnaeus, 1758) (Calappidae De Haan, 1833) y a Astiplax aspera n. gen., n. sp. (Goneplacidae MacLeay, 1838). Aunque C. granulata ha sido previamente reportada del Plioceno de otras regiones de Italia, el ejemplar de Piemonte representa uno de los más completos caparazones conocidos hasta la fecha en el registro fósil de esa especie viviente. El descubrimiento de Astiplax $n$. gen., con A. aspera n. sp., incrementa el número de especies de Goneplacidae del Plioceno de Italia, limitado a Goneplax rhomboides (Linnaeus, 1758) y G. sacci Crema, 1895.

Palabras Clave: Crustacea, Decapoda, Brachyura, Plioceno superior, Italia.

\section{Introduction}

The specimens were discovered in sand blocks crashed by natural erosion along the hills of S. Pietro outcrop located near Asti, Piedmont (NW Italy), in the Astian Pliocene Basin. The yellow sedimentary Asti sands constitute the main body of the surrounding hills, and were deposited in a coastal environment of the old Padano Gulf. The marine Asti sands Fm. is rich in fossils, mainly in molluses, indicating an infralittoral environment (Astiana facies), and was dated to the Late Pliocene (Damarco, 2009). Lacking micropaleontological and sedimentological data, we assign the specimens to the Asti sands Fm. (Late Pliocene) in a generic way. 


\section{Material}

The sample includes two specimens: one carapace dorsally preserved as a three-dimensional mould with the original epicuticle partially preserved; one three-dimensional specimen preserving the carapace and the incomplete right cheliped. The specimens have been assigned to Calappa granulata (Linnaeus, 1758) (Calappidae De Haan, 1833) and Astiplax aspera n. gen., n. sp. (Goneplacidae MacLeay, 1838). The specimens are deposited in the Palaeontological Collections of the Museo di Storia Naturale di Milano (MSNM).

The systematic arrangement used in this paper follows the recent classifications proposed by Castro (2007) and $\mathrm{Ng}$ et al. (2008).

\subsection{Abbreviations}

lc: length of carpus; lcxp: length of carapace; lm: length of merus; wcxp: width of carapace.

\section{Systematic Palaeontology}

Section Eubrachyura de Saint Laurent, 1980

Superfamily Calappoidea De Haan, 1833

Family Calappidae De Haan, 1833

Genus Calappa Weber, 1795

Type species: Cancer granulatus Linnaeus, 1758, subsequent designation by Latreille (1810).

\section{Calappa granulata (Linnaeus, 1758)}

Figure 1

Cancer granulatus Linnaeus, 1758: 627.

Cancer granulatus - Linnaeus, 1767: 533.

Calappa granulata - Garassino and De Angeli, 2004: 38, fig. 4 (1-3). - Garassino et al., 2004: 264, fig. 7 a-c. - De Angeli and Garassino, 2006: 40. - Ng et al., 2008: 48. - De Angeli et al., 2009: 176, 177, 195, 196, fig. 8a, b. - Schweitzer et al., 2010: 82. - Garassino et al., 2012: 51. - Pasini and Garassino, 2013: 320, 321.

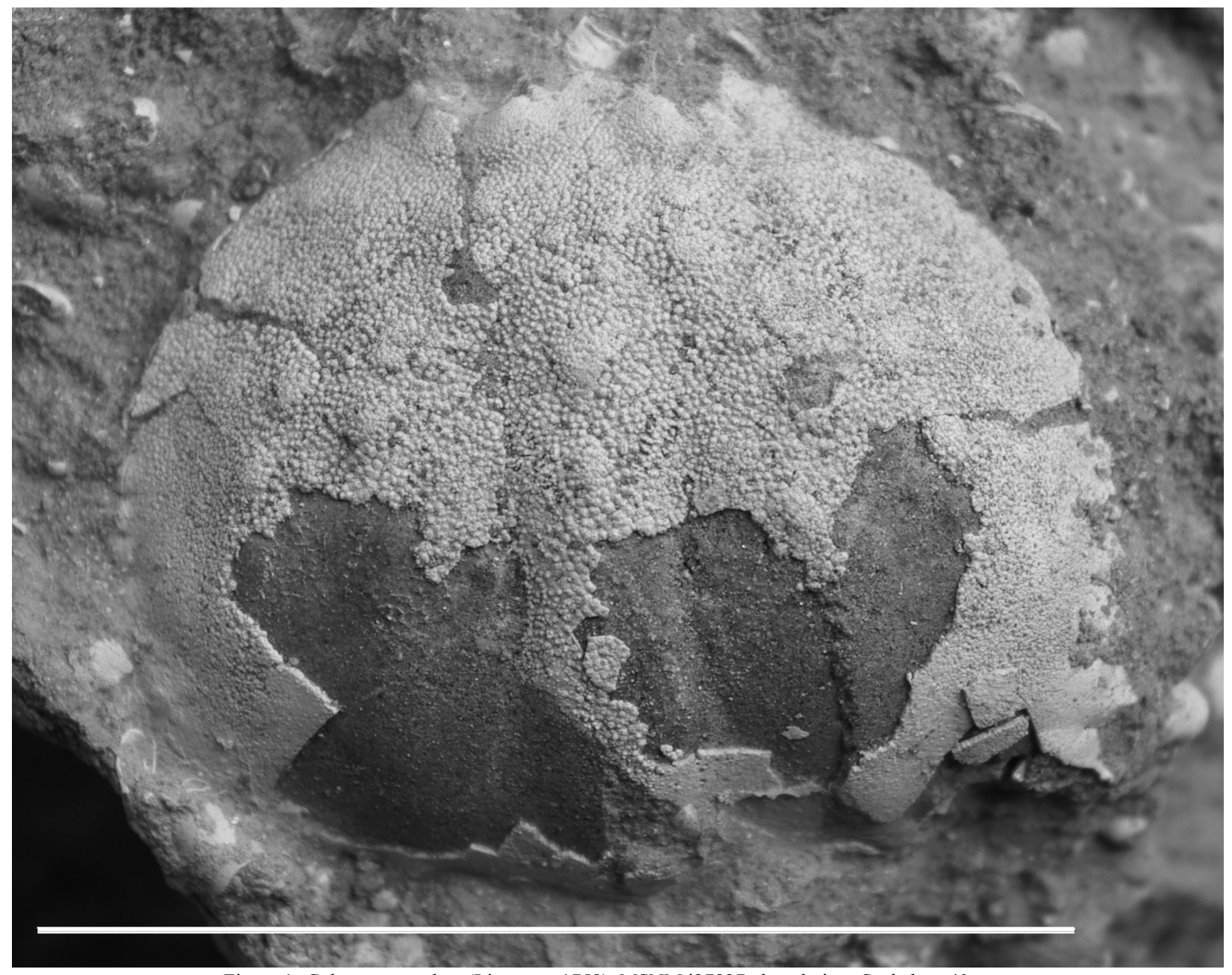

Figure 1. Calappa granulata (Linnaeus, 1758), MSNM i27827, dorsal view. Scale bar: $40 \mathrm{~mm}$. 
Material and measurements: one carapace in dorsal view (MSNM i27827 - lcxp: $33 \mathrm{~mm}$; wcxp: $40 \mathrm{~mm}$ ).

Discussion. The specimen has been compared with the extant species of Calappa Weber, 1795, from the Indo-West Pacific region from which it differs notably in the general shape and ornamentation of the carapace and distribution of the posterolateral teeth ( $\mathrm{Ng}$ et al., 2008); and with the extant and fossil C. granulata, widespread in the Mediterranean Sea.

Zariquiey-Álvarez (1968) pointed out the main characters of this species, such as the convex and wider than long carapace; rounded anterolateral margins; straight posterior margin; poorly produced, bidentate straight front; small well-marked orbits, inferior margin with two small separate teeth; anterolateral margins with small poorly developed teeth wider at the base, followed on the posterior third by four larger teeth pointed medially; posterior margin straight lacking teeth on the median portion; mesogastric and cardiointestinal regions appear fused, forming a prominent longitudinal ridge delimited laterally by two marked longitudinal grooves; at each side of these two grooves, generally four longitudinal grooves not reaching the posterior margin and delimiting other ridges; all the ridges bear longitudinally nodules of decreasing size, with the larger sizes in the mesogastric region; a small nodule is present in the anterior cardiac region; the other regions are covered by granules.

The specimen, although poorly preserved, shows close affinities with $C$. granulata as follows: suboval convex carapace wider than long; straight front and small rounded orbits; raised convex anterolateral margins, with posterior triangular and pointed teeth and nearly straight posterior margin; regions well marked by two longitudinal grooves that divide the carapace in three parts; tuberculate longitudinal ridges and a dense granulation covering the regions, mainly the central dorsal part of the carapace. The specimen is also very similar in shape and ornamentation to the only carapace from the Italian Pliocene of Tuscany reported by De Angeli et al. (2009; 177, fig. 8). Based on these data we attest that the previous reports from the Pliocene of Piedmont, Emilia Romagna, and Sicily and from the Pleistocene of Monte Pellegrino (Sicily) can be assigned to the extant and fossil C. granulata (Ristori, 1891; Gemmellaro, 1914; Garassino and De Angeli, 2004; Garassino et al., 2004; De Angeli et al., 2009; Pasini and Garassino, 2013).

\section{Superfamily Goneplacoidea MacLeay, 1838 Family Goneplacidae MacLeay, 1838 Subfamily Goneplacinae MacLeay, 1838 Genus Astiplax n. gen.}

Diagnosis: carapace transversely rectangular, much wider than long; front slightly turned downwards, not marked by slight median notch or projection; inner edge of supraorbital margin distinct; wide orbits 1.3 longer than front; outer orbital angle without teeth or spines; supraorbital margins strongly sinuous; suborbital margins sinuous, toothless; anterolateral margins slightly convex, toothless; posterolateral margins straight, converging posteriorly; posterior margin long, slightly convex; dorsal surface of carapace conspicuously granular, with slight horizontal ridges, moderately convex, without clear indication of regions; produced lateral knock under the postorbital angles; stout and heavy chelipeds, strongly granulose.

Etymology: from Asti, city located close to the outcrop where the specimen was discovered.

Type species: Astiplax aspera n. gen., n. sp. (gender feminine).

Description: as for the type species.

Discussion. The family Goneplacidae, as reported by Castro (2007), has the following diagnostic characters: carapace transversely rectangular, subquadrate, or trapezoidal; front narrow to wide, typically lamellar, straight; dorsal surface smooth; varying number of anterolateral spines posterior to outer orbital angle (sometimes none but typically one or two); orbits moderately to conspicuously wide, long; fissure in supraorbital margin absent; dorsal surface of carapace typically smooth or with slight horizontal ridges, moderately convex, without clear indication of regions. Most of these characters are present in the specimen, here, assigned to Goneplacidae. Moreover, we justify the erection of the new genus Astiplax based on some supplementary morphological observations. The outer orbital angle and the anterolateral margin of carapace spineless of Astiplax n. gen. are two characters shared with the extant Notonyx Milne Edwards, 1873. The carapace, however, is distinctively quadrate and the typically smooth dorsal surface of Notonyx exclude Astiplax n. gen. from belonging to this genus. The dorsal surface of the carapace of the Astiplax n. gen., with slight horizontal ridges, moderately convex, without clear indication of regions, is a character shared with some species of the extant genera: Carcinoplax H. Milne Edwards, 1852, Pycnoplax Castro, 2007, Goneplax Leach, 1814, Neogoneplax Castro, 2007, Paragoneplax Castro, 2007, and Ommatocarcinus White, 1852 (see Castro, 2007). The dorsal surface of the carapace, however, conspicuously granular in Astiplax n. gen., excludes it from belonging to Pycnoplax, Goneplax, Neogoneplax, and Paragoneplax where the dorsal surface of the carapace is typically smooth. We also exclude it from belonging to Carcinoplax, although slight horizontal ridges and granules along the antero- and posterolateral margins are present in two species, C. cracens Castro, 2007, and C. tuberosa Castro, 2007; as reported by Castro (2007) these are not considered as generic characters. Finally, although the carapace of Ommatocarcinus has slight horizontal ridges, a smooth or conspicuously granular dorsal surface and the anterolateral margin toothless, the outer orbital angles, each with a conspicuous acute tooth, exclude Astiplax n. gen. 
from belonging to this genus.

As reported by Karasawa and Kato (2003) and Schweitzer et al. (2010) the Goneplacidae includes eight fossil genera: Amydrocarcinus Schweitzer, Feldmann, González-Barba and Vega, 2002; Carcinoplax H. Milne Edwards, 1852; Goneplax Leach, 1814; Icriocarcinus Bishop, 1988; Kowaicarcinus Feldmann, Schweitzer, Maxwell and Kelley, 2008; Magyarcarcinus Schweitzer and Karasawa, 2004; Ommatocarcinus White, 1852; Psopheticus Wood-Mason, 1892. Carcinoplax, Goneplax, and Ommatocarcinus are extant genera from which Astiplax n. gen. is excluded. Amydrocarcinus was described from the Eocene Tepetate Fm. (Mexico) (Schweitzer et al., 2002; Schweitzer and Karasawa, 2004), Icriocarcinus from the Late Cretaceous (late Campanian or early Maastrichtian) of San Diego County (California, USA) (Bishop, 1988), Kowaicarcinus from the Pliocene of New Zealand (Feldmann et al., 2008), Magyarcarcinus from the Late Eocene of Hungary (Schweitzer and Karasawa, 2004), and Psopheticus from the Oligocene of Taiwan (Hu and Tao, 1996; Karasawa and Kato, 2003) and the Pliocene of Japan (Karasawa, 1997). We exclude Astiplax n. gen. from these genera not only for geological and paleogeographic implications, but also for the ovoid carapace, small and squared orbits, and the dorsal surface of the carapace typically smooth in Amydrocarcinus; the pentagonal carapace, anterolateral margins with three acute spines, and the dorsal surface of the carapace strongly ridged of Icriocarcinus; the hexagonal carapace, small and ovoid orbits, and tri-lobed anterolateral margin of Kowaicarcinus; the circular carapace, small and ovoid orbits, and smooth dorsal surface of the carapace of Magyarcarcinus; the subquadrate carapace, the outer orbital angle with acute tooth, anterolateral margin with one acute spine, and the dorsal surface of the carapace typically smooth of Psopheticus.

\section{Astiplax aspera n. sp.}

Figures 2-4

Etymology: from the Latin asper, aspera, asperum = rough, alluding to the strong granular ornamentation of carapace and cheliped.

Holotype: MSNM i27828 - specimen, lacking left cheliped, chela of right cheliped, and ambulatory legs (lcxp: $22 \mathrm{~mm}$ (excluding front); wcxp: $32 \mathrm{~mm}$; lm: $20 \mathrm{~mm}$; lc: 8 $\mathrm{mm})$.

Type locality: S. Pietro (Asti, Piedmont, NW Italy).

Geological age: Asti sands Fm., Late Pliocene.

Description. Carapace transversely rectangular, much wider than long; widest at junction between antero- and posterolateral margins; front slightly turned downwards, not marked by slight median notch or projection; inner edge of supraorbital margin distinct; wide orbits 1.3 longer than front, with granular eye-stalk; orbits greatly expanded distally with outer orbital angle toothless; supraorbital margins strongly sinuous, without fissures; sinuous,
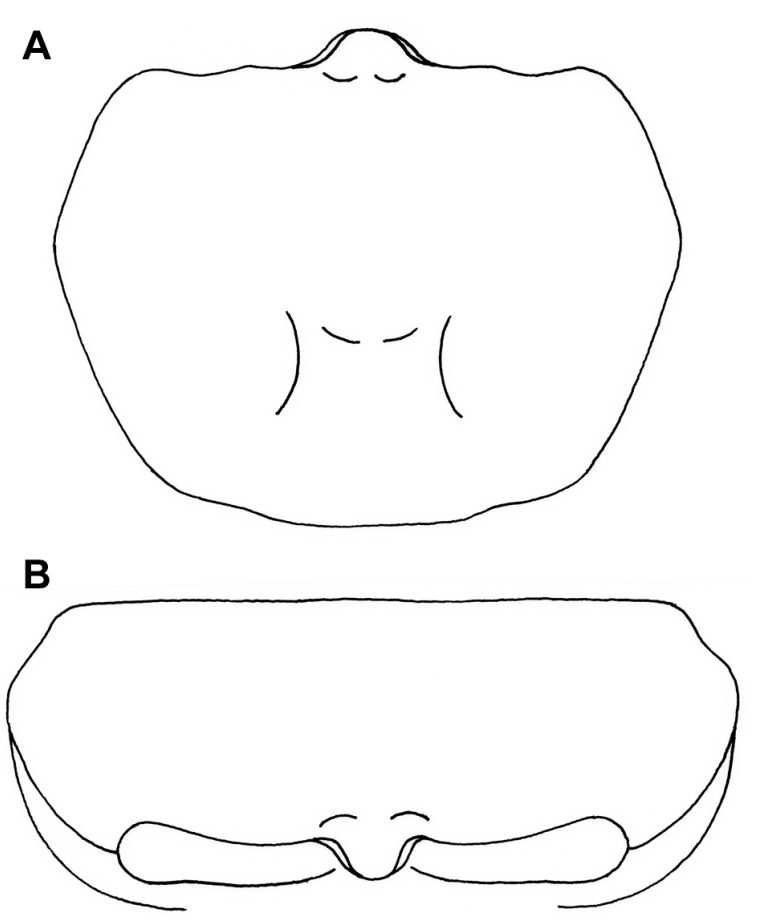

Figure 2. Astiplax aspera n. gen., n. sp. A) reconstruction of carapace in dorsal view. B) reconstruction of the carapace in orbito-frontal of the view.

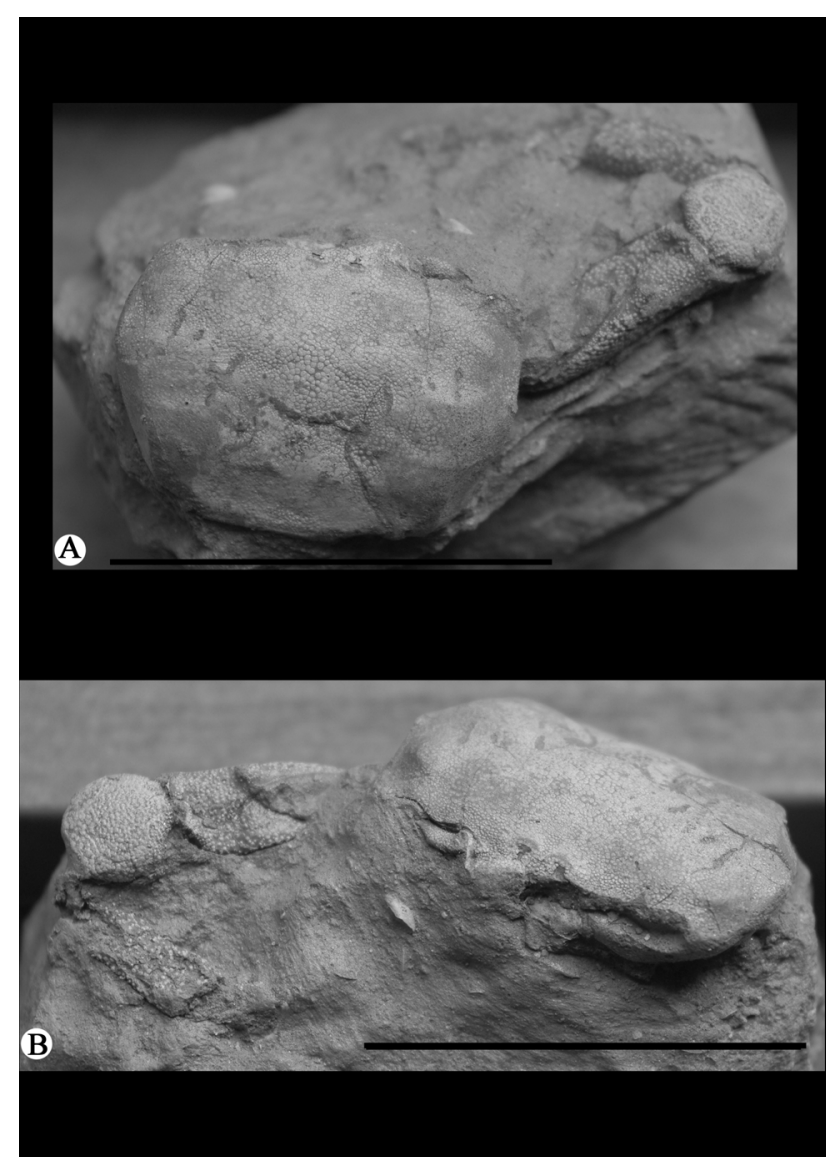

Figure 3. Astiplax aspera n. gen., n. sp., holotype/olotipo, MSNM i27828. A) dorsal view. Scale bar: $35 \mathrm{~mm}$. B) orbito-frontal view. Scale bar $=30$ $\mathrm{mm}$. 


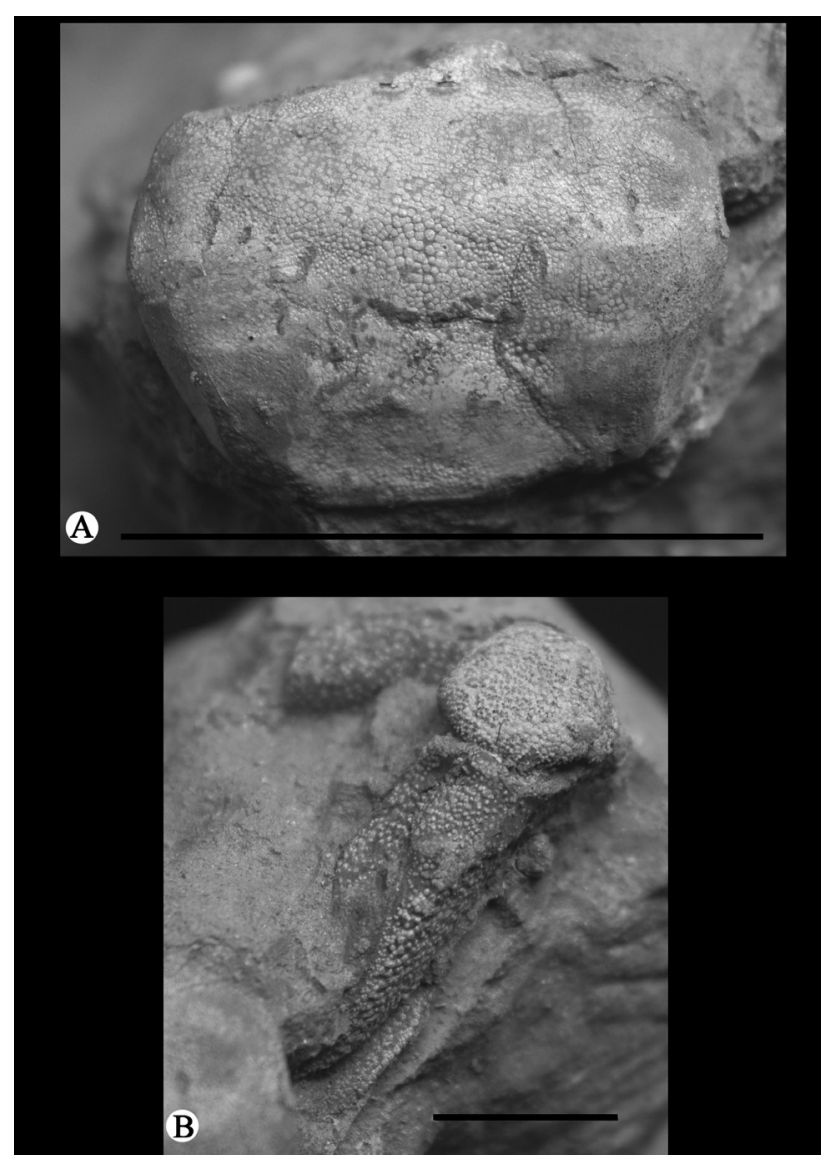

Figure 4. Astiplax aspera n. gen., n. sp., MSNM i27828. A) dorsal surface of the carapace conspicuously granular. Scale bar: $35 \mathrm{~mm}$. B) incomplete right cheliped with granular ornamentation. Scale bar $=10 \mathrm{~mm}$.

toothless suborbital margins; toothless anterolateral margins slightly convex; long, straight posterolateral margins, converging posteriorly; long posterior margin slightly convex; deep gastric pits; branchiocardiac grooves slightly distinct in cardiac region; dorsal surface of the carapace strongly granular, with bigger granules in the metagastric region; slight horizontal ridges, moderately convex, without clear indication of regions; an elevated notch under both postorbital angles, produced forwardly. Stout, heavy cheliped, with moderately long merus, subtriangular in section; carpus subsquare in section, dorsolaterally convex and toothless; merus and carpus surface strongly granular; granules of cheliped bigger than those of the carapace.

Discussion. Among the fossil crabs from the Pliocene of Italy, only Simonellia quiricensis Vinassa de Regny, 1897 (Euryplacidae Stimpson, 1871) from S. Quirico d'Orcia (Tuscany) could be compared with the new genus (Vinassa de Regny, 1897). As reported by De Angeli and Garassino (2006), however, the holotype of this species is lost, making difficult a comparison between the two species based on the published description and the line drawing (Vinassa de Regny, 1897: Pl. 2, figs. 1, 1a). Moreover, this specimen was reported from the clays of S. Quirico d'Orcia (middle Pliocene), younger than the Asti sands Fm. (Late Pliocene) from where the specimen was discovered. Simonellia quiricensis is therefore considered a nomen dubium for not having other specimens of the same species and from the same locality in order to be able to confirm its description. Some characters, reported by Vinassa de Regny, however, distinguish Simonellia from Astiplax n. gen.: the compressed, ovoid carapace, with sharp margins; the small, ovoid orbits; the anterolateral margin with one spine. Finally it is difficult to compare the ornamentation of the dorsal surface of the carapace. Indeed the author described a "scabrous" surface, a term that does not explain if the surface is granular, tubercular or uneven.

\section{Acknowledgments}

We wish to thank P. Frediani (Gruppo Paleontologico "C. De Giuli", Castelfiorentino (Firenze), for useful information on the outcrop, and P. Castro (Biological Sciences Department, California State Polytechnic University, Pomona, USA) for useful suggestions about the systematics of Goneplacidae, careful review and criticism.

\section{References}

Bishop, G.A., 1988, Two crabs, Xandaros sternbergi (Rathbun, 1926) n. gen., and Icriocarcinus xestos n. gen., n. sp., from the Late Cretaceous of San Diego County, California, USA, and Baja California Norte, Mexico: Transactions of the San Diego Society of Natural History, 21(15), 245-257.

Castro, P., 2007, A reappraisal of the family Goneplacidae MacLeay, 1838 (Crustacea, Decapoda, Brachyura) and revision of the subfamily Goneplacinae, with the description of 10 new genera and 18 new species: Zoosystema, 29(4), 609-774.

Crema, C., 1895, Sopra alcuni decapodi terziarii del Piemonte: Atti della Reale Accademia di Scienze di Torino, 30, 664-681.

Damarco, P., 2009, Il Pliocene, in Museo Paleontologico "Giulio Maini", Paleontologia e Geologia, Città di Ovada, 108-122.

De Angeli, A., Garassino, A., 2006, Catalog and bibliography of fossil stomatopoda and decapoda from Italy: Memorie della Società italiana di Scienze naturali e del Museo civico di Storia naturale di Milano, 35(1), 3-96.

De Angeli, A., Garassino, A., Pasini G., 2009, New reports of anomurans and brachyurans from the Cenozoic of Tuscany (Italy): Atti della Società italiana di Scienze naturali e del Museo civico di Storia naturale in Milano, 150(2), 163-196.

De Haan, H.M., 1833-1849, Crustacea, in von Siebold, P.F., Fauna Japonica, sive Descriptio animalium, quae in itinere per Japoniam, jussu et auspiciis superiorum, qui summum in India Batavia imperium tenent, suscepto, annis 1823-1830 collegit, notis, observationibus a adumbrationibus illustravit, Lugduni Batavorum, 1-8, 1-243.

de Saint Laurent, M., 1980, Sur la classification et la phylogénie des Crustacés Décapodes brachyoures I, Podotremata Guinot, 1977, et Eubrachyura sect. nov: Comptes rendus hebdomadaires des Séances de l'Académie des Sciences, (D) 290, 1265-1268.

Feldmann, R.M., Schweitzer, C.E., Maxwell, P.A., Kelley B.M., 2008, Fossil isopod and decapod crustaceans from the Kowai Formation (Pliocene) near Makikihi, South Canterbury, NewZealand: New Zealand Journal of Geology and Geophysics, 51, 43-58. 
Garassino, A., De Angeli, A., 2004, Decapod crustacean fauna from the Pliocene and Pleistocene of Arda, Stirone and Enza Rivers (Piacenza, Parma and Reggio Emilia Provinces, N Italy): Atti della Società italiana di Scienze naturali e del Museo civico di Storia naturale in Milano, 145(1), 29-57.

Garassino, A., De Angeli, A., Gallo, L.M., Pasini G., 2004, Brachyuran and anomuran fauna from the Cenozoic of Piemonte (NW Italy): Atti della Società italiana di Scienze naturali e del Museo civico di Storia naturale in Milano, 145(2), 251-281.

Garassino, A., Pasini, G. Marini, F., 2012, Bathypluma pliocenica n. sp. (Decapoda, Brachyura, Retroplumidae) from the Zanclean (Early Pliocene) of Volterra (Pisa, Toscana, Italy): Atti della Società italiana di Scienze naturali e del Museo civico di Storia naturale in Milano, 153(1), 63-69.

Gemmellaro, M., 1914, Crostacei e pesci fossili del "Piano Siciliano" dei dintorni di Palermo: Giornale di Scienze Naturali ed Economiche di Palermo, 30, 73-94.

Hu, C.-H., Tao H.-J., 1996, Crustacean fossils of Taiwan: Taipei, Taiwan, Republic of China, Ta-Jen Printers, Taipei, Taiwan, 228 p.

Karasawa, H., 1997, A Monograph of Cenozoic Stomatopod, Decapod, Isopod and Amphipod Crustacea from West Japan: Monograph of the Mizunami Fossil Museum, 8, 1-81.

Karasawa, H., Kato H., 2003, The family Goneplacidae MacLeay, 1838 (Crustacea: Decapoda: Brachyura): systematics, phylogeny, and fossil records: Paleontological Research, 7(2), 129-151.

Latreille, P.A., 1810, Considérations générales sur l'Ordre naturel des Animaux composant les Classes des Crustacés, des Arachnides et des Insectes; avec un tableau Méthodique de leurs genres, disposés en familles, Paris.

Leach, W. E., 1814, Crustaceology, in Brewster, D., The Edinburgh Encyclopaedia, 7, 383-437.

Linnaeus, C., 1758, Systema Naturae per Regna Tria Naturae, Secundum Classes, Ordines, Genera, Species, cum Characteribus, Differentiis, Synonymis, Locis, 10(1), 1-824.

Linnaeus, C., 1767, Systema naturae, Volume 1, Pars 2, Editio duodecima, reformata, Holmiae, 533-1327.

MacLeay, W.S., 1838, On the brachyurous decapod Crustacea brought from the Cape by Dr. Smith, in Smith, A., Illustrations of the Zoology of South Africa; Consisting Chiefly of Figures and Descriptions of the Objects of National History Collected During an Expedition into the Interior of South Africa, in the Years 1834, 1835, and 1836; Fitted out by "The Cape of Good Hope Association for Exploring Central Africa": Together with a Summary of African Zoology, and an Inquiry into the Geographical Ranges of Species in that Quarter of the Globe: Invertebratae, 53-71.

Milne-Edwards, A., 1873, Groupe des cyclometopes, Portuniens. Recherches sur la faune carcinologique de la Nouvelle-Calédonie deuxième partie: Nouvelles Archives du Muséum d'Histoire naturelle de Paris, 9, 155-352.

Milne Edwards, H., 1852, Observations sur les affinités zoologiques et la classification naturelle des crustacés: Annales des Sciences Naturelles, Zoologie, ser. 3(18), 109-166.
Ng, P.K.L., Guinot, D., Davie, P.J., 2008, Systema Brachyurorum: Part I. An annotated checklist of extant brachyuran crabs of the world: The Raffles Bulletin of Zoology, Supplement 17, 1-286.

Pasini, G., Garassino, A., 2013, Record of brachyurans from the Pliocene (Piacenzian) of Reggio Emilia Province, Emilia Romagna (N Italy): Boletín de la Sociedad Geológica Mexicana, 65(2), 319-328.

Ristori, G., 1891, Contributo alla fauna carcinologica del Pliocene italiano: Atti della Società Toscana di Scienze Naturali, Memorie, 11, 3-18.

Schweitzer, C.E, Feldmann, R.M., Garassino, A., Karasawa, H., Schweigert, G., 2010, Systematic list of fossil decapod crustacean species: Crustaceana Monographs, 10, 1-222.

Schweitzer, C.E., Feldmann, R.M., Gonzáles-Barba, G., Vega, F.J., 2002, New crabs from the Eocene and Oligocene of Baja California Sur, Mexico and an assessment of the evolutionary and paleobiogeographic implications of Mexican fossil decapods: Journal of Paleontology, memoir 59, 1-43.

Schweitzer, C.E., Karasawa H., 2004, Revision of Amydrocarcinus and Palaeograpsus (Decapoda: Brachyura: Xanthoidea) with definition of three new genera: Paleontological Research, 8(1), 71-86.

Stimpson, W., 1871, Preliminary Report on the Crustacea dredged in the Gulf Stream in the Straits of Florida, by L. F. de Pourtales, Assist U. S. Coast Survey. Part I., Brachyura: Bulletin of the Museum of Comparative Zoology at Harvard College in Cambridge, 2, 109-160.

Vinassa de Regny, P.E., 1897, Contribuzioni alla conoscenza dei crostacei fossili italiani: Simonellia quiricensis n. gen., n. sp. del Pliocene di S. Quirico d'Orcia: Rivista italiana di Paleontologia, 3(5-6), 19-24.

Weber, F., 1785, Nomenclator entomologicus secundum Entomologiam systematicam ill: Fabricii adjectis speciebus recens detectis et varietatibus, $171 \mathrm{pp}$

White, A., 1852, Descriptions of some apparently new species of Annulosa (collected by Mr. Macgillvray during the voyage of H.M.S. Rattlesnake), Appendix no. 6, in Macgillivray J., Narrative of the voyage of H.M.S. Rattlesnake, commanded by the late Captain Owen Stanley, R.N., F.R.S. etc. during the years 1846-1850. Including discoveries and surveys in New Guinea, the Louisiade Archipelago, etc. to which is added the account of Mr. E.B. Kennedy's expedition for the exploration of the Cape York Peninsula. 2, 387-395.

Wood-Mason, J., 1892, Illustrations of the Zoology of the Royal Indian Marine Surveying Steamer Investigator, Under the Command of Commander A. Carpenter R. N., D. S. O. and Commander R. F. Hoskyn, R. N. Crustacea, Part 1, Office of the Superintendent of Government Printing, Calcutta.

Zariquiey-Álvarez, R., 1968, Crustáceos Decápodos Ibéricos: Investigación Pesquera, Barcelona, 32, 1-499.

Manuscript received: July 6, 2012.

Corrected manuscript received: October 20, 2012.

Manuscript accepted: October 22, 2012. 